\title{
Emigrace vrcholových sportovců z bývalého Československa v letech 1948-1989
}

\author{
Migration of elite athletes from former Czechoslovakia in years \\ 1948-1989
}

\author{
Jakub Válek
}

Olomouc, ¿̌R

\begin{abstract}
Abstrakt
Článek se zabývá emigrací českých a slovenských sportovců z bývalého Československa v letech 1948 až 1989, tedy v období vlády tzv. „diktatury proletariátu“. Jednalo se o sportovce olympijských sportů, minimálně mistrů republiky a reprezentantů evropské či světové úrovně. Metodou heuristickou a analýzy dokumentů bylo dohledáno 271sportovců (212 mužů a 59 žen) ve 37 olympijských sportech. Článek podává prehled o četnosti podle sportovních odvětví, o destinacích, kde se sportovci-emigranti usadili, o motivech a způsobu emigrace a bisexuálních rozdílech. Vètšina z nich byla $v$ nové hostitelské zemi velice úspěšná, jak po sportovní, tak i profesní stránce. Někteři se už do své bývalé vlasti nevrátili, jiní tak učinili po změně politického režimu ve svobodném Československu po roce 1989 a část z nich žije strídavě v obou zemích. Odchod těchto osobností nám dokládá, kolik náš bývalý stát ztratil na mezinárodní prestiži, protože úspěšní sportovci jsou jak v minulosti, tak v současnosti nejlepší reklamou, výkladní skříní daného státu a jeho politického zřízení.
\end{abstract}

\begin{abstract}
The presented article deals with the migration of the Czech and Slovak sportsmen out of former Czechoslovakia within the years 1948-1989, i.e. under the rule of the so called "working mass dictatorship". The sportsmen recruited from the elite level, minimal level was the winning in national championship, European or World level success, only in Olympic sports. Heuristic historical method and documents analyses were used for data collection. 271 sportsmen were found ( 212 male, 59 female) in 37 Olympic sports. Survey of frequency of sportsmen-migrants involved in sports types, destination of domestication, motives and gender differences are described. The majority of elite sportsman-migrants were successful in new life both in sports and professional domains. Some of them never came back, some of them returned after political changes in free Czechoslovakia 1990 or they have been living alternately in each country.
\end{abstract}

Klíčová slova: emigrace, Československo v letech 1948-1989, vrcholoví sportovci, olympijské sporty

Keywords: emigration, elite athletes, Czechoslovakia in years 1948-1989, Olympic sports

\section{ÚVOD}

Emigrace je komplexní celospolečenský jev, který se kontinuálně prolíná celým historickým vývoje lidstva. $\mathrm{V}$ dnešním slova smyslu jde o jev především sociologický a je spojen s vytvořením státních útvarů a hranic mezi nimi.

Průmyslová revoluce a kolonialismus byly přičinou masové emigrace už v 17. a 18. století, kdy Evropané migrovali za prací do Afriky a Asie, později do Ameriky a Austrálie. Paralelně miliony Afričanů nedobrovolně migrují na otrokářské práce v USA. Hlavními zeměmi přijímajícími 
imigranty v 19. století byly Británie, Německo, Francie, Amerika, Austrálie. První světová válka, ekonomická krize a xenofobie zvýšily vlnu emigrace. Emigrace je vyvolávána vždy zásadními společensko ekonomickými změnami (války, politické převraty) a následně hledáním podmínek přežití, podmínek dodržování lidských práv, což ovšem s uplatněním profesním a pracovním souvisí (Hadaš, 2010). Prvotní je „přiliv mozků” a kvalifikovaných pracovníků, později př́liv imigrantio nekvalifikovaných. Vytvárejí se i typické migrantské sítě (např. Mexiko, Filipíny, Indie, Pakistán, Cína, tzv. východní zemé Evropy do USA). (Castles \& Miller, 2003, 225).

Vlny emigrantů, hledajících práci v době ekonomické krize meziválečných let dvacátého století, se už intenzivně účastní také obyvatelé tehdejšího Československa (fenomén sportu tehdy ještě neexistoval).

Jedním z grantových projektů Akademie věd ČR je téma „Vědci v emigraci“, tudíž prezentované téma „sport a emigrace“ by mělo být považováno za téma relevantní. Čeští vědci v exilu 1948-1989 (Štrbáňová, Spížek, Josefovičová \& Závěta, 2011).

Emigrace vrcholových sportovců je dodnes docela běžným světovým jevem. Je typická především pro sportovce $z$ ekonomicky chudých a politicky nestabilních zemí. Např́íklad sportovci (především atleti a fotbalisté) z bývalých kolonií, nejen Afriky, ale i Oceánie, Latinské Ameriky a Karibiku, dnes reprezentují nejčastěji země svých původních evropských koloniálních velmocí (U. K., Francie, Nizozemí, Belgie, Itálie, Španělsko, atd.). V posledních dvaceti letech atleti, ale i jiní sportovci, směřuji do arabských ropných velmocí nebo bohatých států Evropy. Průkopníkem byl olympijský vítěz a mistr světa na 800 m Nelson Kipketer z Keni, který se stal mistrem Evropy už jako reprezentant Dánska. Po rozpadu SSSR zamíril velký počet ruských a ukrajinských sportovců židovského původu, a to z profesních a výkonnostních důvodů, do Izraele. Podobně ruští sportovci, kteří nenajdou uplatnění v reprezentaci své země, se dnes objevují v národním dresu Kazachstánu či jinde. Aktuální je př́iběh bývalé ruské reprezentantky Anastasie Kuzminy, dvojnásobné olympijské vítězky z biatlonového sprintu na ZOH 2010 ve Vancouveru a ZOH 2014 v Soči, už ale v barvách reprezentace Slovenska. Obdobná je i situace u sportovců bývalé Jugoslávie nebo Turecka, ale ti miŕí především za rodinami do Německa, Rakouska apod. Touto problematikou se zabývá např́klad Bale a Sang (1994), Meguire (2002) nebo Taylor (2005). Fenomén emigrace v bývalém Československu (respektive ČSSR) reálně existoval, ovšem byl tabuizován. V povědomí jsou převážně mediálně velmi známé osobnosti (např. tenisté, lední hokejisté a krasobruslaři), o méně známých se nevědělo. Záměrem výzkumu bylo prozkoumat veškeré nezodpovězené otázky týkající se emigrace sportovců bývalého Československa (respektive ČSSR), konkrétně pokusit se nalézt osobnosti vrcholových sportovců, identifikovat je a popsat jejich uplatnění v nové destinaci. Tedy i osobnosti dosud mediálně méně známe, leč vrcholové úrovně. Výše uvedené informace a myšlenky byly motivem proto, aby tato problematika byla postupně důkladněji zpracována do kohezivnějšího celku, který by vyústil v celistvou práci o emigraci českých a slovenských sportovců vrcholové úrovně v letech 1948 - 1989. Předložená stat podává první, byt ještě ne úplný přehled na základě dostupných pramenů a materiálů. Smyslem dalšího výzkumu je postupně téma rozvinout, kompletovat a v pozdějším období dokonce rozššrit o emigraci vrcholových sportovců z celého původního „východního bloku“ (Válek, 2011b).

\section{METODIKA}

Užívaný termín „emigrant“ má v práci emotivně a normativně neutrální obsah, fakt opuštění Československa, i když byly tendence v Československu ve sledovaném období dávat tomuto termínu pejorativní nádech (Procházka, 1962).

V celé práci, pokud není uvedeno vysloveně jinak, je používáno jednotného čísla termínu sportovec nebo emigrant a v množném čísle sportovci nebo emigranti jen v mužském rodě, přičemž veškeré tyto termíny jsou aplikovány stejně tak pro ženský rod. Budiž tomu rozuměno tak, že je tak učiněno pouze $\mathrm{z}$ praktických a gramatických důvodů. 
Vymezení hledané populace emigrantů - vrcholových sportovců. Kritériem pro vymezení hledané populace byla určena tři hlediska (Válek, 2011a):

1. geografické - to znamená, že se narodili na území bývalého československého státu nebo jeho předchůdců. Pro zjednodušení můžeme říkat, že jde o kritérium národnostní, že daný sportovec (sportovkyně) je považován za Čecha nebo Slováka;

2. výkonnostní - hledaní sportovci se stali mistry Československa nebo alespoň jednou reprezentovali Československo v mezistátním utkání nebo na mezinárodní scéně;

3. sportovní odvětví - z důvodu zúžení tématu byl brán zřetel pouze na sportovce, kteří výše daného výkonnostního kritéria dosáhli aspoň v jednom sportovním odvětví, které je zařazeno do programu olympijských her. Toto je např́klad důvod, proč se v této statistice nevyskytují jiní velmi známí sportovci z neolympijských sportů. Jako př́íklad lze uvést golfistu světové extratřídy Alexandra Čejku nebo špičkové šachové velmistry Lubomíra Kaválka, Lud’ka Pachmana a Vlastimila Horta.

\section{Sběr dat}

Po metodické stránce byly použity „metody sběru dat“ (prrístup heuristický) a „metody zpracování“ dat (analýza) a interpretace dat (syntéza), tedy přístup kausální.

Metody sběru dat byly postaveny na hledání a zajištění pramenů čili na heuristice, dále na studiu a analýze dokumentů a literatury. V historiografii mají termíny pramen a literatura specifický význam. Pramen zde představuje prvotní zdroj informací v tom smyslu, že je „nejblíže“ minulé skutečnosti - je totiž její součástí nebo ji bezprostředně odráží, kdežto literatura obsahuje informace již odvozené a vyvozené z pramenů (Bartoš \& Kovářová, 2005). Jednalo se především o písemné primární prameny (archivy sportovních federací, kroniky, archivy a ročenky klubů). Významným zdrojem těchto primárních pramenů byl Ústav pro studium totalitních režimů v Praze a jeho archiv bezpečnostních složek, kde se také nachází kartotéka emigrace. Protože se zde nacházejí údaje a informace z celého původního československého státu v letech 1948 - 1989, nebylo nutné se tolik zaměřit na podobnou instituci na Slovensku, tedy na Ústav pamäti národa, sídlící v Bratislavě. Dále pak šlo o písemné prameny sekundární (beletrie a časopisecké články o sportovcích, internetové zdroje, v neposlední řadě i dvě závěrečné magisterské práce, u kterých jsem působil jako vedoucí: Hromek, 2002; Nykl, 2003). Nedílnou součástí metodiky sběru dat této práce byla také orální historie.

Zpracování dat bylo řešeno logickou heuristickou a historickou analýzou. Kritika pramenů probíhala $v$ rovině vnější i vnitřní a je úzce spojena s interpretací pramenů. Obě fáze se vzájemně prolínají a doplňují. Pramen nelze vytrhávat ze souvislostí, nelze jej odděleně zkoumat (Zwettler, 1996). Jako základní historiografická metoda byla požita metoda chronologická.

\section{EMIGRACE ČESKÝCH A SLOVENSKÝCH VRCHOLOVÝCH SPORTOVCŮ V LETECH 1948-1989}

Podstatnou část 77 let trvající existence společného státu Čechů a Slováků (Československo: 1918-1938 a 1945-1992) zaujímá období pod vládou jediné strany (KSČ: 1948-1989). Již od počátku 90. let se snaží historikové vyrovnat s předcházející čtyřicetiletou epochou. Historická metodologie uvádí, že ke kritickému zhodnocení minulosti je vhodný odstup deseti až dvaceti let (Bartoš, 1999). Na Filosofické fakultě Univerzity Palackého v Olomouci (Centrum pro Československá exilová studia) se řeší komplexní tématika exilová. Do tématu zapadá i zmapování emigrace osobností ze sféry sportu (sportovci/sportovkyně, př́ip. trenéři). Někteří z nich se uplatnili také ve sportovních reprezentacích nových zemí, někteří nikoliv (bylo by zajímavé dopátrat se i přícin, proč tomu tak bylo).

Někteři odcházeli již jako malé děti se svými rodiči nebo jako neznámí teprve nadějní sportovci a výrazně se prosadili až v novém domově. Typickým př́kladem je např́iklad plavec Alexander 
Baumann, který se narodil v Praze a se svými rodiči emigroval v pěti letech do Kanady. V roce 1984 se stal už jako kanadský občan dvojnásobným olympijským vítězem. Nebo Stanislav Gvoth (Guoth), rodák z liptovské vesnice Sokolče, kterého rodiče po únorovém převratu poslali za př́buznými do Kanady. Stan se pak stal, už s převzatým jménem Mikita po strýci, jako hráč Chicago Black Hawks jedním z nejlepších a nejúspěšnějších hokejistů NHL v 60. a 70. letech. Dalším zajímavým př́kladem je také lední hokejista Petr Nedvěd, rodák z Liberce, který již v sedmnácti letech na začátku kariéry opustil výpravu HC Litvínov na turnaji v Kanadě. Prosadil se mezi nejlepší hráče NHL, dostal kanadské občanství a získal s kanadským výběrem stř́brnou medaili na ZOH 1994 v norském Lillehammeru. V roce 2007 se vrátil zpět do České republiky, dodnes hraje Českou hokejovou extraligu a dokonce se v roce 2012, na sklonku své sportovní kariéry vrátil, tentokrát už do dospělé, české hokejové reprezentace a dostal se s ní i na ZOH 2014 v ruském Soči.

Převážná část sportovců však odcházela v době své nejlepší sportovní výkonnosti, na vrcholu své sportovní kariéry, protože ve své vlasti již neměli čeho více dosáhnout a směřovali do zemí, kde se hrála nejkvalitnější soutěž světa (např. lední hokejisté), nebo do zemí, které jim umožňovaly svobodné a neomezené cestování, které potřebovali za splněním svých sportovních snů a ambicí (tenisté a krasobruslaři).

Někteří emigrovali až na sklonku sportovní kariéry s cílem finančně zabezpečit sebe a své rodiny do budoucnosti. Ještě větší počet sportovců emigroval s rodinami až po skončení kariéry, klidně i s větším časovým odstupem, a to z důvodu, že se v nové zemi věnovali svým civilním povoláním a dost často v rozčarování a zklamání z neměnící se, naopak zhoršující se politické a ekonomické situace $\mathrm{v}$ bývalém Československu. Toto bylo typické především pro sportovce, kteří emigrovali po srpnu 1968 a v roce 1969. Rada z nich totiž v té době pobývala na tréninkových stážích v zahraničí, kam je v době politického uvolnění v roce 1968 vysílalo ÚV ČSTV.

Zajímavá jsou také zjištění o uplatnění následné generace prvních emigrantů. Mezi nimi můžeme najít např́íklad taková jména jako je wimbledonský vítěz v tenise Richard Krajicek z Nizozemí, dvojnásobný mistr světa $v$ alpském lyžování Kanad’an Ed Podivinsky nebo z poslední doby olympijský vítěz v krasobruslení z Vancouveru 2010 Evan Lysacek z USA a další.

\section{EMIGRACE JAKO ŽIVOTNÍ KŘIŽOVATKA}

Emigrovat znamená změnit dosavadní styl života, opustit své zaměstnání a rezignovat na postavení v práci, zrušit přečetné mezilidské vztahy (opustit příbuzné, přátele a známé), opustit vlast, kulturní hodnoty, vzdát se majetku (Diamant, 1995).

Většina emigrantů může na vlastní emigraci nahlížet jako na následek prvního svobodného rozhodnutí v totalitním systému, který do té doby rozhodoval za ně. Každý z emigrantů měl vlastní pohnutky (motivy), at to již byly motivy a) idealistické (svoboda na Západě, život v demokratické společnosti, možnost sebeuplatnění v kapitalistické společnosti včetně dosažení vyšších výkonnostních standardů); b) ideologické (život dle vlastního přesvědčení, svoboda náboženského vyznání, možnost vyjádřit, zastávat a bránit vlastní názory); c) etické (život dle vlastních morálních zásad, zachování morálních principů předků, jež byly v rozporu s marxismem-leninismem); d) materiální (život ve společnosti s vyšší ekonomickou úrovní, možnosti vyššího životního standardu, dům, auto, cestování, podnikání, pohodlí; (Diamant, 1995).

Přesto, že tato práce je prací historickou, dotýká se biografií daných osobností a souvisí s psychikou člověka. Fenomén opuštění domova a domovského kontextu je v žebříčku životních zátěžových situací považován za čtvrtý nejvýznamnější (po ztrátě partnera, ztrátě dítěte, rozvedení-rozloučení s partnerem). Opuštění vlasti patří bezesporu k závažným životním krokům, jež dlouhodobě či natrvalo poznamenávají život jedince, jeho okolí a mnohdy i jeho potomků. Frankl (2006) řadí opuštění vlasti k mezním životním situacím, jako jsou například prrírodní katastrofy, války a pobyt v koncentračním táboře. Opuštění vlasti, at již z jakýchkoliv důvodů, lze považovat za proces dlouhodobě zatěžující individuum tím, že jej staví do nových situací, kterým se musí 
přiměřeně a rychle přizpůsobit v zájmu sebezáchovy, uchování osobní integrity, duševního zdraví, kvality života, produktivity a tvořivosti. Podstata opuštění vlasti neboli emigrace podle Diamanta (1995) spočívá v ne-akceptovatelnosti odstupu v čase a prostoru od aktuální situace ve vlasti, jež je pro daného jedince nevyhovující a již není schopen změnit. Pro posouzení vlivu opuštění vlasti na duševní život jedince a jeho okolí je především důležitá motivace, tedy zda vlast se opouští z donucení (nedobrovolně) či z vlastního rozhodnutí a zda se smí či může vrátit. Podobný názor zastává i Janečková (2005) nebo Madson (1979) v teorii o naplnění sekundárních potřeb.

Přestože k opuštění domova došlo převážně ze svého rozhodnutí, at už předpokládané motivy a subjektivní důvody byly bazální, existenční (šikana, mobbing či ostrakismus sportovců v tehdejších domácích podmínkách), stejně jako ekonomické zvýhodnění oproti domácí situaci, ale i jiné, většinou sportovně-výkonnostní, vždy to však bylo rozhodnutí zásadní, ovlivňující nejen samotného sportovce, ale i celý jeho rodinný kontext. Toto rozhodnutí, tedy vlastně životní křižovatka, může být jedním jedincem vnímána jako negativní, kdežto jiným jedincem jako osvobozující. Teorii životních křižovatek rozpracoval Koščo (1987). Osoba v etapě rozhodování o emigraci nebo v emigraci samé je vystavena různým situacím, které jeho další životní cestu ovlivňují. Diamant (1995) uvádí tři hlavní psychologické problémy emigrace a to jsou adaptace, integrace a deprese.

Detaily z průběhu osobního života nebylo možné v předložené studii podchytit detailněji, přesto v našich stručných biografiích se objevují vzestupy a úspěšná pokračování, a to hlavně u tenistů, krasobruslařů a ledních hokejistů (M. Navrátilová, I. Lendl, sourozenci Jelínkovi, sourozenci Romanovi, O. Nepela, bratři Štastní, P. Klíma, P. Svoboda, P. Nedvěd, D. Volek, atd.). Stejně tak můžeme najít př́íklady sportovců, kteří se neuchytili (např. R. Tajcnár), těch ale nebylo mnoho. Většinou tomu tak bylo jen z důvodu, že emigrovali až na sklonku sportovní kariéry, tedy už byli v podstatě za výkonnostním zenitem (Válek, 2011b).

Hodně sportovců emigrovalo v době po skončení sportovní kariéry, kdy se již věnovali nové trenérské nebo jiné civilní profesi, což je typické hlavně pro druhou posrpnovou emigrační vlnu. I ti byli vcelku úspěšní, i když mnohdy skončili jen v regionálních klubech. Tito sportovci, často i se svými rodinami, vlastně neměli jinou možnost než se prosadit a uplatnit v nové společnosti. Protože, kdyby to vzdali a vrátili se domů do vlasti, byli by perzekuováni, čekaly by je výslechy a odsouzení na odnětí svobody v rozmezí jednoho až pěti let. To vše podle nechvalně známého zákona č.231/1948 Sb. Jde o zákon, který na návrh vlády přijalo Národní shromáždění ze dne 6. řijna 1948 Na ochranu lidově demokratické republiky, kde v Hlavě IV. Trestné činy proti mezinárodním vztahům, bylo překročení hranice kvalifikováno podle $\S 40$ Neoprávněné opuštění území republiky a neuposlechnutí výzvy k návratu. „Československý občan, kterýv úmyslu poškodit zájem republiky opustí neoprávněně území republiky nebo ve stejném úmyslu neuposlechne výzvy úradu, aby se v přiměrené lhůtě, kterou mu úřad určí, na území republiky vrátil, bude potrestán pro zločin těžkým žalárem od jednoho do pěti let“. K tomu se pojil ještě $§ 59$ Podmíněné odsouzení, který však platil pouze pro osoby mladši 18 let, dále $\S 47$ Peněžitý trest a $§ 57$ Přikázání do donucovací pracovny (http://www.totalita.cz/texty/1948-231.php).

V lepším případě by sloužili stávajícímu režimu jako loutka pro masmédia za účelem vyzdvihování lidově demokratického, později socialistického státního zřizení a očerňování politického a společenského života na Západě (např. J. Drobný, R. Farda, V. Nedomanský).

Tehdejší politický systém měl ve vztahu k sportovcům, kteří emigrovali, dvě základní taktiky. Pokud nebyl daný sportovec dost mediálně známý, ( $\mathrm{tj}$. z mediálně ne př́liš populárních sportů nebo když se nepohyboval v top sportovní společnosti), snažil se režim vše kolem jeho emigrace utajit, aby se pokud možno nedostalo nic na veřejnost a tato událost byla co nejrychleji zapomenuta. Pokud však šlo o sportovce mediálně velice známé, a to i celosvětově, nedala se tato událost zamlčet. Proto nastupovala druhá varianta, taktika pomluv a očerňování charakteru, sportovní výkonnosti, ale i o tom, jak se mají tito sportovci v cizině špatně a jak by se nejraději vrátili, ale pro tyto zrádce už u nás není žádné místo. Tato taktika byla $\mathrm{z}$ velké míry neúspěšná, protože o tyto špičkové sportovce (převážně to byli tenisté, krasobruslaři a lední hokejisté) se dál velice zajímala světová masmédia a naši lidé se o nich dozvídali v zahraničí nebo z cizích rozhlasových 
a televizních stanic, např. ZDF a ORF. Hlavně však z pravidelného vysílání Rádia Svobodná Evropa a Hlasu Ameriky. Každopádně jejich rodiny a př́buzní byli doma často perzekuováni. Měli problémy v zaměstnání, často o ně dokonce i přišli a museli dělat jinou méně kvalifikovanou práci. Podobné problémy měli i při studiu na středních a vysokých školách. Obdobné potiže měli také ve sportu. Např́klad sourozenci, kteři také sportovali na vrcholové úrovni, se jen těžko dostávali do reprezentačních výběrů. Pokud na reprezentaci dosáhli, měli velké problémy s vycestováním k mezistátním zápasům (např. Marián Štastný nebo Miroslav Ihnačák). Ovšem problematika cestování, a to nejen do kapitalistické ciziny, byla shodná pro všechny rodinné př́slušníky. Tento problém byl vlastně totožný pro celou tehdejší společnost, až na úzkou skupinu prominentů.

O všech těchto výše uvedených skutečnostech nejlépe vypovídají vyšetřovací spisy StB (Státní bezpečnost). Svazky čítají mnohdy několik stovek stránek, které jsou dnes k vědeckým účelům dostupné v Ústavu pro studium totalitních režimů v Praze a v Ústavu paměti národa v Bratislavě. Tyto svazky jsou plné výpovědí a výslechů rodičů a rodinných příslušníků, přátel, sousedů, spoluhráčů, trenérů a sportovních funkcionářů. Nejčastější dotazy jsou na motivaci emigrace, zda o tom někdo nevěděl, jak se jim v zahraničí daří a kdo a jak je s nimi v kontaktu.

\section{FAKTA O ČETNOSTI SPORTOVNÍCH OSOBNOSTÍ EMIGRACE Z HLEDISKA SPORTOVNÍCH ODVĚTVÍ, POHLAVÍ A LOKALIZACE HOSTITELSKÝCH ZEMÍ}

Důležité a zajímavé je srovnání četnosti emigrace vypátraných sportovců u jednotlivých sportovních odvětví. Jednoznačně na prvním místě je lední hokej, u kterého bylo dohledáno podle daných kritérií 47 sportovců, což je skoro jedna pětina ze všech 271 zjištěných. Důvodem je jistě to, že v celém zkoumaném období naši hokejisté patřili mezi světovou elitu a byl tudíž o ně velký zájem i v zahraničí. Měli možnost cestovat a srovnávat životní podmínky u nás a v cizině, sami měli motivaci výkonnostně růst a v neposlední řadě také chtěli sebe a své rodiny ekonomicky zabezpečit, protože jejich sportovní kariéra trvala kolem 15 let. Kromě těchto 47 dohledaných a ověřených hráčů ledního hokeje máme neúplné indicie i o dalších emigrantech, které vyžadují doplnění.

V roce 1986 emigrovali do USA Vojtěch Kučera a Karel Svoboda (starší bratr Petra Svobody), neprosadili se v NHL a hráli pouze za farmářské celky. Mnohem zajímavější jsou však další informace z knihy Jiř́iho Macků: Utajené stránky hokejové historie I. Zapřené generace (Vyškrtnuti z historie, vymazáni z paměti), kde na straně 105 a 106 v kapitole „Udělat něco komunistům na truc“, autor uvádí další významné hokejové emigranty, které nebylo možné nikde vypátrat (jejich jména jsou zvýrazněna): „Díky hokeji mohou první nejtěžší období překlenout i ostatní, nejen všude žádaný Maleček. Zábrodský pưsobí dvě sezóny jako hrajicí trenér v Lausanne, jeho kolegou na stř́lačce Davosu je Sláma. V̌̃estranný Kučera má v Bernu trojnásobný trenérský úvazek, Matouše získá Cortina, Raba zůstává ve Švédsku ve službách Hammarby, nějakou dobu ve Stockholmu hraje i Marek, dres rakouského Klagenfurtu oblékaji Schejbal a Suchopárek. “...

„Zámérem bylo vytvorit silný exilový tým, který by svobodně šíril slávu čs. hokeje a pritom byl noční můrou komunistického režimu, se po kolektivním návratu LTC ze Spenglerova poháru v prosinci 1948 nikdy neuskuteční. Zi̊stane jenom splněné prání různě roztroušených emigrantů alespoň jednou si spolu zahrát. Stará myšlenka exilového týmu na chvíli ožije v zemi, kterou jako hokejisté znaji nejlépe a která byla většinou cílem jejich prvních kroků: ve Švýcarsku. Ujme se jí Oldřich Zábrodský, začátkem roku 1950 rozešle pozvánky do všech koutů Evropy, jedna putuje i na zvlášt vzácnou adresu Bucknovu až do kanadského Trailu, reakce jsou nadšené. Nový tým je švýcarským svazem zaregistrován pod názvem $O$. K. Lions. Ke krátkému vzpomínkovému turné se staviteli sjedou do obrany vypomoci Maleček a Sláma, pro útoky jsou k dispozici Schejbal, Kučera, Matouš, Ulrich, Suchopárek, Roubík a Novák. Omluva dorazí jenom od Jiřího Taussiga-Tesaře, bývalého gólmana I. ČLTK (v brance musí zaskočit junior z HC Lausanne), ve Švédsku působícího Marka a údajně kdesi v Rakousku pobývajícího Lonsmína." (Macků 2004, s. 105, 106).

$\mathrm{Na}$ dalším místě je atletika s 29 dohledanými emigranty, ale ta je dost specifická, protože vět- 
šina $\mathrm{z}$ nich emigrovala hned po roce 1948 a většina se potom sportem zabývala jen okrajově a věnovala se civilnímu zaměstnání. Zajímavý je např. příběh atletického družstva, které v roce 1947 zvítězilo na armádním mistrovství světa v německém Hannoveru. Zatímco Martínek s Roudným a Zátopkem zůstali v Československu, Kořán, Vomáčka a Zabloudil po únoru 1948 emigrovali a živili se jako úspěšní podnikatelé či vědci. Další pořadí četnosti emigrovaných sportovců je následující: tenis 21 , volejbal 18 , plavání 17 , krasobruslení 16 , fotbal a veslování po 14 a vodní slalom 12 dohledaných emigrantů ( $v$ žádném jiném sportu již nebylo vypátráno více jak devět sportovců). Tyto sporty mají společný jeden rys, a tím je možnost volného cestování k mezistátním utkáním a soutěžím do zahraničí. Zatímco už u několikrát uvedeného tenisu, krasobruslení a také fotbalu byla možnost dalšího výkonnostního růstu a ekonomických podmínek spojená se svobodným cestováním, u ostatních sportů kromě této volnosti a do jisté míry svobody cestování nebylo možné očekávat žádné další velké výkonnostní a ekonomické výhody. Obecně lze poměrně velkou četnost emigrace u těchto sportů přisuzovat tomu, že šlo také o převážně typické vysokoškolské sporty a procento emigrace vysokoškoláků bylo, jak je známo, výrazně vyšší než u běžné populace, zvláště ve spojení se zahraničními zkušenostmi těchto sportovců. Navíc tito sportovci často brzy svou sportovní kariéru ukončili a věnovali se trenérské činnosti nebo jinému civilnímu povolání a sportu se věnovali pouze rekreačně nebo jen na výkonnostní úrovni.

Když se podrobněji podíváme na počet dohledaných sportovců a sportovkyň, kteří v daném období opustili Československo, dojdeme k celkovému počtu 271 sportovců, z toho bylo 212 mužů (tj. $78,2 \%$ ) a 59 žen ( $21,8 \%$ ), což je poměr zhruba $4: 1$. Tento výrazný nepoměr lze snadno vysvětlit následujícími př́ícinami:

1. celkový počet vrcholových sportovců je větší než sportovkyň, což platí především pro období po druhé světové válce a v padesátých nebo šedesátých letech. Zde je jasná spojitost s celospolečenským a sociálním pohledem na tzv. úlohu ženy ve společnosti. Dnes je již situace odlišná a tento poměr se pomalu vyrovnává;

2. z pohledu na tabulku četnosti dohledaných emigrantů podle sportovního odvětví vyplývá, že většího počtu ženy sportovkyně dosáhly jen u typicky ženských a hlavně ekonomicky atraktivních sportů jako je 10 identifikovaných sportovkyň v atletice, stejně tak v krasobruslení, v tenise jich pak bylo identifikováno 9 . V žádném jiném sportovním odvětví ženy nepřesáhly číslo 5 , dokonce u čtrnácti sportů, tj. zhruba u poloviny, se nepodařilo nalézt ženu, která by odpovídala daným kritériím. U mužů, když nepočítáme běh na lyžích a biatlon, kde nebyl dohledán vưbec žádný sportovec, jsou to pouze jediná dvě sportovní odvětví, a to synchronizované plavání a moderní gymnastika, tedy typické ženské sporty. Právě větší počet ryze mužských sportů je také důvodem tohoto nepoměru. Proti tomu je ve výrazném kontrastu mužský a samozřejmě ekonomicky velice zajímavý lední hokej s počtem 47 ;

3. posledním logickým důvodem tohoto nepoměru je, že žena, at svobodná nebo vázaná na rodinu, mnohem více a důkladněji zvažuje své další osobní a rodinné možnosti a perspektivy budoucího působení v zahraničí, stejně tak i důsledky své emigrace pro život rodiny a prríbuzných, kteři zůstali doma v Československu.

Zajímavý je také pohled na to, kam a jakým způsobem tito sportovci emigrovali, i když i pro tento fakt jsou logická vysvětlení. Důležité bylo, zda sportovec emigroval během sportovní kariéry nebo až po jejím skončení. Za druhé, jestli emigroval sám nebo i s rodinou. V potaz nelze brát emigraci v dětském věku, kdy odpovědnost za veškerá rozhodnutí nesli pouze jejich rodiče. Pokud sportovec emigroval sám, tak to bylo většinou během nějakého sportovního zájezdu, at už to bylo dopředu plánované (nap̌r. A. Vrzáňová, J. Maleček, V. Nedomanský, R. Farda, M. Navrátilová, I. Lendl, atd.) nebo šlo o nahodilou a okamžitou myšlenku (M. Sláma, O. Zábrodský, J. Drobný, P. Klíma, P. Svoboda, P. Nedvěd, atd.). Pokud se snažili emigrovat s celou rodinou nebo jen s partnerem, tak to bylo převážně během dovolené (V. Nedomanský, R. Farda, F. Musil, M. Géry atd.). Nejčastějším a nejsnazším způsobem použivaným ve druhé emigrační vlně byla dovolená u moře v bývalé Jugoslávii a odtud směřování přes tranzitní zemi, což bylo většinou Rakousko, dále do místa, kde se chtěli později usadit. 
U 243 sportovců z 271 se podařilo vysledovat zemi, kam emigrovali nebo kde se usadili, což dělá 89,7 \% ze všech dohledaných sportovců emigrantů. Hostitelskými zeměmi byly samozřejmě státy s vysokou sportovní tradicí a hlavně také zároveň státy s vyspělou ekonomikou a propracovaným sociálním systémem. Jsou to tedy dvě hlavní oblasti: Evropa (133 sportovců, což je 54,8 \%) a Severní Amerika (96 sportovců, což je 39,5 \%). Ještě v Austrálii a na Novém Zélandě bylo dohledáno 11 sportovců, což je $4,5 \%$ a na všechny ostatní světové destinace zbývají celkově jen 3 dohledaní sportovci, což dělá pouhé $1,2 \%$ z celkového počtu dopátraných destinací.

Evropa byla častější v první emigrantské vlně, protože byla dostatečně známá a byla dostatečně blízko bývalého Československa, protože emigranti z let 1948 a 1949 ještě věřili a doufali, že se někdy brzo vrátí domů. Emigranti, z řad sportovců, zamírili především do Německa ( 52 sportovců $=21,4 \%$ ), Švýcarska (31 sportovců $=12,8 \%$ ), ale také do Rakouska (14 sportovců $=5,8 \%$ ), Švédska, Itálie a Velké Británie (všude po 8 dohledaných sportovcích, což je po 3,3 \%), v menší míře pak do států Beneluxu (5 sportovců) a Španělska (4 sportovci).

Severní Amerika (USA a Kanada) je logicky více svázána s druhou emigrační vlnou po srpnu 1968 a je typická pro krasobruslaře (lední revue), tenisty (celoroční tréninkové podmínky např. na Floridě) a lední hokejisty (možnost hrát NHL). Z 96 dohledaných sportovců se usadilo $55(22,6 \%)$ ve Spojených státech amerických a v Kanadě pak zbylých 41 sportovců, tj. 16,9\% $\mathrm{z}$ celkového množství. Kromě výše uvedených sportů sem zamiŕili také někteří atleti, plavci, vodní slalomáři i jiní sportovci.

Mimo tyto dvě hlavní geografické oblasti bylo nalezeno již jen 14 dohledaných sportovců $(5,8 \%)$. Jen dva naši bývalí českoslovenští sportovci emigrovali do Jižní Ameriky (atlet K. Zabloudil do Venezuely a boxer F. Louda do Brazílie), v Kapském městě v JAR se usadil volejbalista V. Voříšek a na Novém Zélandě další volejbalista J. Frundl. Poměrně početná byla jen skupina, která se usadila v Austrálii. Tam našlo nový domov 10 sportovců (např. atlet V. Sadila, sjezdař A. Šponar, plavec P. Šuba nebo veslaři M. Pupala a M. Walter), což je 4,1 \% z celkového počtu dohledaných světových destinací.

Výše uvedené statistické výsledky jsou brány celkově bez ohledu na to, zda šlo o první nebo druhou emigrační vlnu. Když se zaměříme tímto směrem, musíme konstatovat, že z 271 dohledaných sportovců, kteří emigrovali v daném období, bylo u 239 (což je 88,2\% z celkového počtu) prokázáno, že emigrovali bud' v první emigrační vlně poúnorové ( 68 sportovců $=28,45 \%)$ nebo ve druhé emigrační vlně posrpnové (171 sportovců $=71,55 \%$ ). U 32 sportovců nelze s jistotou prokázat, zda se jednalo o vlnu první nebo druhou.

\section{ZÁVĚR}

Celkem se podařilo nalézt a dohledat 271 československých sportovců, kteří v daném období emigrovali z Československa, soutěžili ve výše specifikovaném sportovním odvětví a naplňovali výkonnostní kritéria. Nejedná se zatím o ucelený přehled skutečně emigrovaných sportovců. Jsou mezi nimi i sportovci, kteří emigrovali již dětství spolu se svými rodiči a kteří svých sportovních úspěchů dosáhli až ve své nové hostitelské zemi. I tak lze říci, že jde o nezanedbatelný počet (271osob), hlavně když přihlédneme k počtu medailí, které získali na olympijských hrách, mistrovstvích světa a mistrovstvích Evropy. K tomu musíme připočíst případné další československé sportovce, kteří v daném období taktéž emigrovali, ale nepodařilo se je zatím dohledat, identifikovat a nalézt dalši informace.

Dnes se můžeme již jen dohadovat, jaký je konečný počet, kolik a jakých dalších sportovních úspěchů mohli dosáhnout, kolik medailí z ME, MS a OH by tito sportovci ještě získali? Nebo kolik dalšich neprímých úspěchů, kdy tito sportovci dále působili jako trenérí? Jaký počet dalších budoucích reprezentantů a medailistů ještě mohli vychovat? 


\section{Referenční seznam}

Bale, J., \& Sang, J. (1994). Out of Africa: The "development" of Kenyan athletics, talent migration and the global sports systém. In J. Bale \& J. A. Meguire (Eds.), The global sports arena: Athletic talent migration in a independent World, (pp. 206-225). London: Frank Cass.

Bartoš, J. (1999). Úvod do metodiky historického bádání a nauky o pramenech. Olomouc: Univerzita Palackého.

Bartoš, J., \& Kovářová, S. (2005). Nauka o historických pramenech. Olomouc: Univerzita Palackého.

Castles, S., \& Miller, M. J. (2003). The Age of Migration [3rd ed.]. New York, NY: Palgrave Macmillan and The Guilford Press.

Diamant, J. (1995). Psychologické problémy emigrace. Olomouc: Matice cyrilometodějská s.r.o.

Frankl, V. E. (2006). A přesto ríci životu ano: psycholog prožívá koncentrační tábor [2nd ed.]. Praha: Karmelitánské nakladatelství. Hromek, M. (2002). Sportovní emigrace v letech 1948 - 1968 v kontextu emigračních vln českého národa. Diplomová práce. Olomouc: Univerzita Palackého, fakulta tělesné kultury.

Hadaš, K. (2010). International Skill Flows: Academic Mobility and Brain Gain. In "European Higher Education for the World 2 - Studies on international students' mobility and brain gain" project, (pp. 115-122). Poznan: European social Fund.

Janečková, H. (2005). Životní události a kvalita života. In Payne, J. et al. (Eds.), Kvalita života a zdraví, (pp. 451-472). Praha: Triton.

Koščo, J. et al. (1987). Poradenská psychológia. Bratislava: Slovenské pedagogické nakladatel'stvo,

Macků, J. (2004). Utajené stránky hokejové historie l. Praha: TYPO JP.

Madson, K. B. (1979). Moderní teorie motivace. Praha: Academia.

Meguire, J. (2002). Sport worlds: A sociological perspectives. Champaign, IL: Human Kinetics.

Nykl, J. (2003). Sportovní emigrace v letech 1968-1989. Diplomová práce. Olomouc: Univerzita Palackého, Fakulta tělesné kultury.

Procházka, V. et al. (1962). Př́ruční slovník naučný [l. díl]. Praha: Nakladatelství Československé akademie věd.

Štrbáňová, S., Spižek, J., Josefovičová, M. \& Závěta, K. (2011). Čeští vědci v exilu 1948-1989 [Výzkumný grant No. IAAX00630801 AV ČR, 2008-2011].

Taylor, T. (2005). Communist Sport Policy: Past, Present and Future. In D. Kluka, G. Schiling \& W. F. Ster (Eds.), Perspectives: Aspects of Sport Governance, (pp. 51-78). Oxford: Meyer \& Meyer Sport (UK) Ltd.

Válek, J. (2011a). Emigrace českých a slovenských sportovců v letech 1948 - 1989. Nepublikovaná doktorská disertační práce. Bratislava: Univerzita Komenského, Fakulta telesnej výchovy a športu.

Válek, J. (2011b). Specifika emigračních vln československých vrcholových sportovců v

letech 1948-1989. Česká kinantropologie, 15(4), 29-38.

Zwettler, O., Vaculík, J., \& Čapka, F. (1996). Úvod do studia dějepisu a technika historikovy práce. Brno: Masarykova univerzita. 